\title{
Communication strategy to disseminate the results of the evaluation of the Port-of-Spain Declaration (POSDEVAL) across multiple audiences in the Caribbean
}

\author{
Natalie S. Greaves, ${ }^{1}$ Joan Tull, ${ }^{2}$ Trevor Hassell, ${ }^{3}$ and T. Alafia Samuels ${ }^{2}$
}

Suggested citation

Greaves NS, Tull J, Hassell T, Samuels TA. Communication strategy to disseminate the results of the evaluation of the Port-of-Spain Declaration (POSDEVAL) across multiple audiences in the Caribbean Rev Panam Salud Publica. 2018;42:e186. https:/ / doi.org/10.26633/RPSP.2018.186

\begin{abstract}
Like many nations in the Americas, the countries of the Caribbean are facing increasing morbidity and mortality associated with noncommunicable diseases (NCDs). In 2007, based on advocacy by Sir George Alleyne and others, the Caribbean Community (CARICOM) convened the first in the world Heads of Government NCDs Summit. This summit issued the Port of Spain Declaration that served not only as a rallying point to accelerate the regional NCDs response, but also as a catalyst for the first United Nations high-level meeting on NCDs in September 2011.

In 2014, seven years after the CARICOM NCDs Summit, a formal evaluation of the Port of Spain Declaration (POSDEVAL) was conducted to investigate its impact and learn lessons to support and further accelerate its implementation. One mechanism was to review successes and challenges in the NCDs response and effectively communicate findings to stakeholders and the public.

The results of the evaluation and the implementation of the Port of Spain Declaration are presented by other papers in this supplement. The present paper describes the communication and social information process used for sharing POSDEVAL findings across multiple layers of social influence in the Caribbean, primarily in 2016 - 2017. The main steps of the communication process are shared as a possible strategy for disseminating NCDs research information and accelerating control and policy adoption in other Small Island Developing States and middle-income countries.
\end{abstract}

Keywords Health communication; noncommunicable diseases; health policy; Caribbean region.

Among the 49 nations in the Americas, premature mortality from noncommunicable diseases (NCDs) is highest in the Caribbean, with $40 \%$ of

\footnotetext{
Faculty of Medical Sciences, the University of the West Indies, Bridgetown, Barbados.

George Alleyne Chronic Disease Research Centre, Caribbean Institute for Health Research, the University of the West Indies, Bridgetown, Barbados. Send correspondence to T. Alafia Samuels, alafia.samuels@cavehill.uwi.edu

Healthy Caribbean Coalition, Bridgetown, Barbados.
}

related deaths occurring among those $30-69$ years of age $(1-4)$. In response, the Caribbean Community (CARICOM) held the world's first Heads of Government Summit on NCDs, and issued the Port-of-Spain (POS) Declaration "Uniting to Stop the Epidemic of Chronic Non-Communicable Diseases," (3).

The POS Declaration comprises 15 mandates to be monitored annually through 26 indicators (3). Strategic actions include: reducing risk factors; developing a "whole-of-society," "whole-of-government" response; designing legislative frameworks; improving surveillance; and the launch of an annual Caribbean Wellness Day $(3,4)$.

From 2014 - 2017, a research team led by the George Alleyne Chronic Disease Research Centre (GA-CDRC; The University of the West Indies, Bridgetown, Barbados) 
conducted a formal evaluation of the POS Declaration (POSDEVAL). The POSDEVAL was performed on behalf of the Pan American Health Organization/World Health Organization (PAHO/WHO) and CARICOM, with funding from the Canadian International Development Research Centre (IDRC), a center committed to translating knowledge into effective policy (5).

The overarching objective of the POSDEVAL was to evaluate progress made during the 7 years since the POS Declaration and to use the lessons learned to accelerate and support continued implementation, as well as to inform the United Nations High-level Meeting on NCDs. POSDEVAL included six research and two dissemination objectives. The latter were included to facilitate improvements in the policy responses to NCDs through the timely translation of research into policy and programs $(3-5)$.

Implementation of the Declaration and POSDEVAL results are presented by other papers in this special issue of the Pan American Journal of Public Health. The present paper focuses on the communication and social information process used for sharing POSDEVAL findings across multiple layers of social influence in the Caribbean, primarily in 2016 - 2017.

The timely dissemination of information was a critical aspect of the POSDEVAL process. There was an explicit need to share findings throughout CARICOM Member States, and globally, as a means of bolstering implementation (4). Therefore, an evidence-based strategy was used to operationalize aspects of Diffusion of Innovations Theory (6), in particular the principles of (a) engaging with the wider social system as a means of influencing individual behavior and (b) identifying and engaging stakeholders who could either hinder or accelerate desired change by virtue of their role as opinion leaders. The strategy for disseminating POSDEVAL findings across multiple layers of social influence, including an outline of the human resources needed, is covered in detail here and serves as an example of integrated knowledge transfer informed by the Social Ecological Model of Behavior Change $(7,8)$.

\section{POSDEVAL STRATEGY FOR DISSEMINATING INFORMATION}

\section{The PICO}

Key to the success of the dissemination process was the role of Public Information and Communications Officer (PICO), created during the second year of the project. Having more than 20 years of experience in journalism and communications in the Caribbean, the recruited PICO was knowledgeable on effective ways of disseminating information in the area's particular sociocultural context. In addition, the PICO's academic and professional skill set included project management and experience in behavior-change communications.

The PICO was responsible for developing an evidence-based strategy aimed at ensuring the timely dissemination of results for the purpose of accelerating change at both the policy and individual levels. As such, it was imperative that the PICO's dissemination plan achieve strategic alignment among the emerging evaluation findings, the key messages to be developed, and the characteristics and information needs of the intended target audiences. Given this, the dissemination strategy was iterative and adaptable over the life of the project. To facilitate a seamless flow of information, from findings to dissemination, the PICO worked closely with senior project staff, reporting directly to the project's Principal Investigator (PI) and the co-PI (Figure 1).

The PICO was funded through a project sub-contract with a leading, regional, civil society NCD advocacy network, the Healthy Caribbean Coalition (HCC). This collaboration was beneficial as in addition to funding, the HCC helped the PICO understand the characteristics and needs of key potential target audiences

FIGURE 1. Organizational chart: Port of Spain Declaration evaluation's senior project staff, including the Public Information and Communications Officer (PICO)

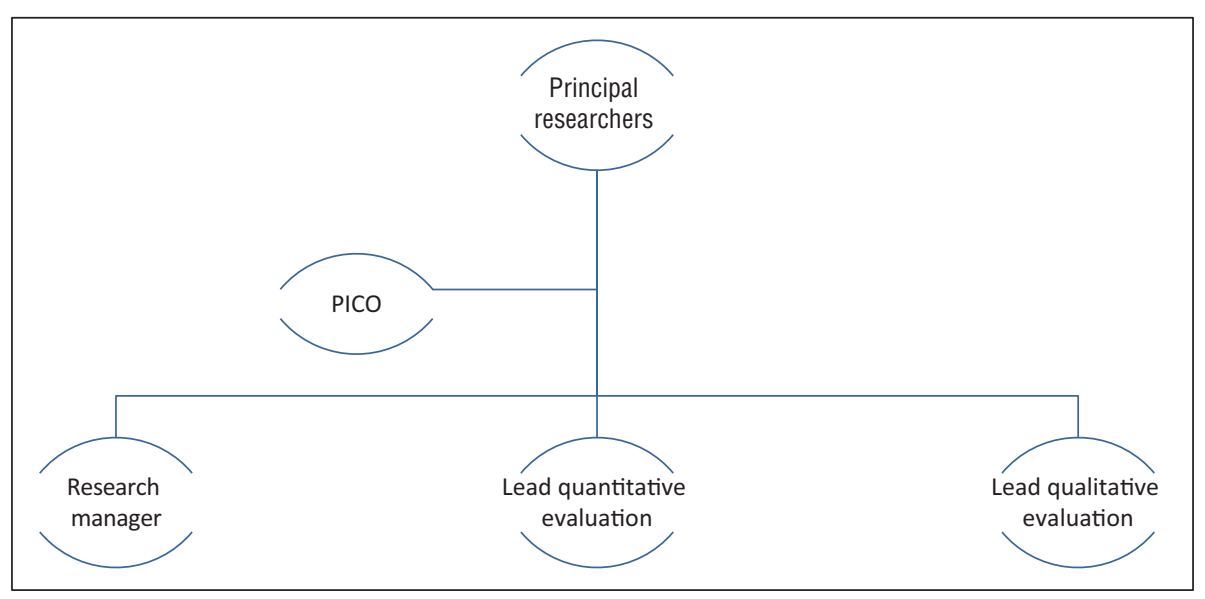

Source: Prepared by the authors from study data. for whom information was being packaged.

\section{Communicating across layers of social influence}

The evaluation's dissemination strategy sought to deliberately engage with the widest possible cross-section of society as part of the mechanism for combatting NCDs through a "whole-of-government" and "whole-of-society" approach (9). To this end, as findings emerged from the evaluation, they were tailored to meet the needs of specific groups, from policymakers and civil society organizations to the women and men in the streets. Descriptions of the methods for disseminating to specific target groups follow.

Dissemination to policymakers. The dissemination strategy sought to engage with this audience, which was charged with adopting and implementing laws and policies, or to reinforce and support existing policies. Policymakers included: regional health bodies, such as $\mathrm{PAHO} / \mathrm{WHO}$ and the Caribbean Public Health Agency; health and non-health ministries and agencies, such as Ministries of Agriculture, Trade, and Education; and national NCD commissions or their equivalents. As findings emerged, they were distilled into short, succinct key messages and "asks" for policymakers. The messages were then communicated in written and oral form by the PI who played the unique role of researcher and NCDs advocate.

Key "asks" for policymakers and signs of success. The central "asks" for the most senior policy-level audience, 
namely the CARICOM Heads of Government, related to: banning smoking in public places; banning fast food advertisements directed at children; and raising taxes on sugar sweetened beverages and foods high in sugar, salt, and trans-fats.

The evidence supporting these requests was shared with senior policymakers during a 2-year process spearheaded by the evaluation's PI/NCDs advocate. Formal presentations of the final report were made to Ministers of Health at international inter-governmental meetings; and briefings were also conducted with CARICOM health officials and others. These meetings not only shared the evaluation's findings, but were also solutions-oriented, involving discussions on new initiatives for preventing NCDs and a rational approach to treatment of NCDs across the Caribbean $(10-14)$.

Briefing packages were sent to senior technical civil servants to be given to health and wellness focal points in all of the CARICOM Member States. The focal points included chief medical officers, principal nursing officers, and national NCDs advocates. Engaging directly with senior technical civil servants and other policymakers to achieve translation of research results was highly successful, resulting in CARICOM leaders making new commitments to tackle the epidemic of chronic diseases. Specifically, the 2016 communiqué stated:

As the Tenth Anniversary of the historic Port of Spain Declaration, "Uniting to Stop the Epidemic of Non-Communicable Diseases (NCDs)" draws near, the Heads of Government recognized the progress made in addressing the issue. They acknowledged, however, that progress was variable and agreed to adopt a more holistic approach. In this regard, they pledged to address issues such as the banning of smoking in public places; trade related measures; banning advertisement of potentially harmful foods which specifically target children; and elevating taxes on foods high in sugar, salt and trans-fats.

-CARICOM Heads of Government Conference, July, 2016 (15)

Furthermore, in 2017 at the $38^{\text {th }}$ CARICOM Heads of Government Conference in Grenada, an entire session was devoted to action against NCDs. During this session, the leaders discussed draft measures aimed at establishing the Caribbean as a tobacco-free zone by 2022. The Heads of
Government also decided to look closely at measures, in particular taxation and education, aimed at changing dietary practices, such as eating high-salt, highsugar, fatty foods, and drinking sugar-sweetened beverages. All of these have increased among many, especially the young. A commitment to fighting childhood obesity was also discussed (16).

Dissemination to non-policymaker audiences. The broader, secondary audiences were thought of as those who ideally had a key role to play in keeping the Port of Spain Declaration and its NCDs messaging agenda visible and at the forefront of the public's attention. As such, this group included: health care professionals and providers, academics, the physical activity industry, civil society organizations (health and non-health), and the private sector, especially food manufacturers, distributors, a retailers, and the fast food industry.

Thus, the evaluation's dissemination process sought to reach a diverse audience and achieved this by hosting a series of workshops and town hall meetings with a wide range of stakeholders. One such civil society meeting in Jamaica brought together consumer action groups, fishermen's representatives, the Chamber of Commerce, running-event organizers, journalists, the private sector, police officers, dieticians, faith-based organizations, civil society groups, and academics.

Dissemination to the general public. The focal areas of the information campaign to the public was to raise awareness of the existence of the Port of Spain NCDs Declaration itself, the lessons learned from the evaluation, and the way forward. There was also considerable emphasis placed on practical ways for the people of the Caribbean to lead healthier lives. The main instruments for engagement were traditional media and the project website- established and updated by the HCC with content provided by the PICO. Social media was supported by the HCC social media consultant. Importantly, the University of the West Indies loaned the support of its marketing assets to the project, which helped enhance opportunities for engagement through newspapers, radio, and television. In addition, the CARPHA Regional Health Communications Network-a group of health journalists, educators, and media practitioners-also supported the project.
In framing the dissemination of information strategy for the public, it became apparent that a brand was necessary. To this end, the PICO oversaw the design of a culturally resonant and relevant slogan, "Caribbean Unity in Health," and logo (17). Interestingly, the slogan had been suggested by a member of the public during a canvassing exercise. The slogan and accompanying logo were used consistently on all disseminated materials. In addition, a vivid array of stories, photographs, and videos were created to tell the narrative of the evaluation's results and to mark key dates on national and regional NCD awareness calendars, such as World Diabetes Day and World Obesity Day. This multimedia approach comprised interviews with key personalities and testimonials by those affected by NCDs and their caregivers, as well as vignettes on NCD prevention activities by civil society organizations throughout the Caribbean. Also key to achieving a wide reach was the website and the use of social media.

Website. A website targeting secondary audiences was launched simultaneous to efforts to share results with the primary (policymaker) audience. The website www.onecaribbeanhealth.org was updated regularly and was intended to become a galvanizing forum for those involved in the NCDs response. It evolved into a Caribbean open access NCDs repository, freely available online, with evidence briefs, fact sheets, and summaries of various aspects of the epidemic and the response- diet, food and food security, agriculture and trade policies, and tobacco control. In addition, the website contained a series of action guides for various sectors, from civil society and schools to faith-based and private-sector organizations (15).

Social media. Social media tools, such as Facebook and Twitter, were also used to disseminate NCDs information to primary and secondary audiences since 2016. These tools were intended to be used as mechanisms for increasing traffic to the website, www.onecaribbeanhealth.org.

Traditional media. The dissemination strategy also engaged traditional media avenues, in particular, "opinion-formers" such as editors, influential columnists, and print media commentators. Engaging opinion-formers contributed to the use of a multi-step flow model of communication where key findings or messages shared with opinion-formers might gain additional weight and cur- 
rency with the general population, hopefully prompting increased action.

\section{From key "asks" to core accelerating actions}

As well as "asks" and messages, select stakeholders within the primary and secondary audience groups were provided with specific information to inform strategic programming and interventions. For example, nongovernmental organizations focused on health were offered guidance on forming NCD alliances to harmonize their work; manufacturers were shown evidence to support discussions around reformulation of their products; and Ministers of Health were provided data that could be used to inform discussions around taxation of sugar-sweetened beverages.

Therefore, the key building blocks of the PICO's strategy used multiple forms of media to engage the whole-of-society in its response to the increasing morbidity and mortality associated with NCDs in the Caribbean. The mechanisms used to monitor and evaluate the success of the dissemination strategy are briefly described below.

\section{Signs of success with the non- policy audience}

Realistically, the fundamental metric of the communication strategy was, "How much interest or traction did the evaluation and the healthy lifestyle issues it raised get in the media?" The answer was measured using website traffic volumes and media mentions. As of September 2017, the onecaribbeanhealth.org website had achieved 64586 unique visits and 127 647 total page impressions, while the Facebook page had attracted some 1250 likes.

Print media monitoring was undertaken and showed that some 47 articles, mostly driven by reported interventions by the PI/NCDs advocate, appeared in regional and national newspapers and on websites. The PI also took part in television and radio interviews. Press engagement was: Barbados = 16, Grenada = 1, Guyana $=1$, Jamaica $=9$, St. Lucia $=3$, St. Maarten $=2$, Trinidad $=3$, Regional $=7$, International $=$ 5. There were also media appearances, including: PI/NCD advocate interview for UWI-TV, PAHO TV, and Good Morning Barbados, as well as radio interviews in several countries, including Antigua and Barbuda, Dominica, Grenada, Jamaica, and Trinidad and Tobago.

\section{KEY LEARNINGS}

The dissemination strategy used in the Port of Spain evaluation was novel and strategic. Its success fundamentally hinged on three factors: (a) the establishment of the PICO role; (b) performance of the PI as both researcher and NCDs advocate; and (c) the ability to harness and access media resources at low or no cost to reach the widest possible multisectoral audience.

The importance of developing and integrating strategies for disseminating information, based on behavioral theories integrated with research processes that inform policy decisions, cannot be overstated. Lessons learned from POSDEVAL show that the translation of evidence into policy is not only influenced by the level of a country's democratization, organization, and bureaucratic functionality, but also by how evidence is framed and packaged with regards to societal norms $(18-20)$. In light of this, the POSDEVAL communication strategy considered the societal norms and multiple layers of social influence in accordance with the Social Ecological Model (8). This model is a behavioral theory stating that an individual's choice to adopt and maintain health-related behaviors is determined by multiple layers of social influence (Table 1). These layers include an individual's interpersonal relationships and their community and public policy environments.

A holistic approach to communication, such as the POSDEVAL strategy, requires a PICO and a team knowledgeable in health promotion, health education, behavior-change theories, communication, and epidemiology. In individual Small Island Developing States, it is unlikely that the entire human resource skillset would be available; however, this project has shown that through multisectoral, regional, and international collaboration, communication goals can be successfully achieved through lower-cost interventions, including existing social media platforms (Figure 2).

While multiple models are proposed for closing the research-policy-practice gap, engaging the practitioners in the research process enhances translation (21 - 23). These POSDEVAL dissemination efforts were able to take advantage of the legitimate and authoritative positioning of the PI/NCDs advocate to access a policy window of opportunity using multiple modes of dissemination to increase uptake and utilization of results

TABLE 1. Target audiences for dissemination of Port of Spain Declaration evaluation (POSDEVAL) study positioned within the respective layers of social influence of the Social Ecological Model

\begin{tabular}{|c|c|c|c|}
\hline $\begin{array}{l}\text { Social } \\
\text { influence }\end{array}$ & Target audience & $\begin{array}{l}\text { Examples of the modes } \\
\text { of disseminating information }\end{array}$ & $\begin{array}{l}\text { Facilitators of effective } \\
\text { communication of POSDEVAL findings }\end{array}$ \\
\hline Interpersonal & $\begin{array}{l}\text { Immediate social network of } \\
\text { Caribbean people-friends, family, } \\
\text { coworkers, }\end{array}$ & $\begin{array}{l}\text { One Caribbean website, Twitter, Facebook, television } \\
\text { "talk- show" appearances by Principal Investigator } \\
\text { (PI)/Noncommunicable Diseases (NCDs) Advocate }\end{array}$ & $\begin{array}{l}\text { Multisectoral collaboration and funding of the role of the Public } \\
\text { Information and Communications Officer through the Healthy } \\
\text { Caribbean Coalition }\end{array}$ \\
\hline Organizational & $\begin{array}{l}\text { Schools, faith-based and private } \\
\text { sector organizations }\end{array}$ & Researcher facilitated workshops & Legitimacy of the PI/NCDs Advocate \\
\hline Community & $\begin{array}{l}\text { Community leaders including the } \\
\text { media, academia, and health } \\
\text { professionals }\end{array}$ & $\begin{array}{l}\text { Workshops, targeted literature, and written } \\
\text { communication in the print media }\end{array}$ & $\begin{array}{l}\text { Free access to regional mass media resources and some } \\
\text { localized print houses through multisectoral collaborations }\end{array}$ \\
\hline Policy & $\begin{array}{l}\text { Policy makers throughout the } \\
\text { Caribbean region-Heads of } \\
\text { Government, } \\
\text { senior technical civil servants }\end{array}$ & $\begin{array}{l}\text { Written documents including policy briefs; } \\
\text { presentations at high level meetings }\end{array}$ & Facilitated by hybrid role of researcher/advocate \\
\hline
\end{tabular}

Source: Prepared by the authors from study data and based on the model by Golden SD, Earp JL. Social ecological approaches to individuals and their contexts: twenty years of health education \& behavior health promotion interventions. Health Ed Behavior. 2012;(39):364-72. 
FIGURE 2. Main steps in the Port of Spain Declaration evaluation (POSDEVAL) communication strategy with recommendations (denoted by a + sign)
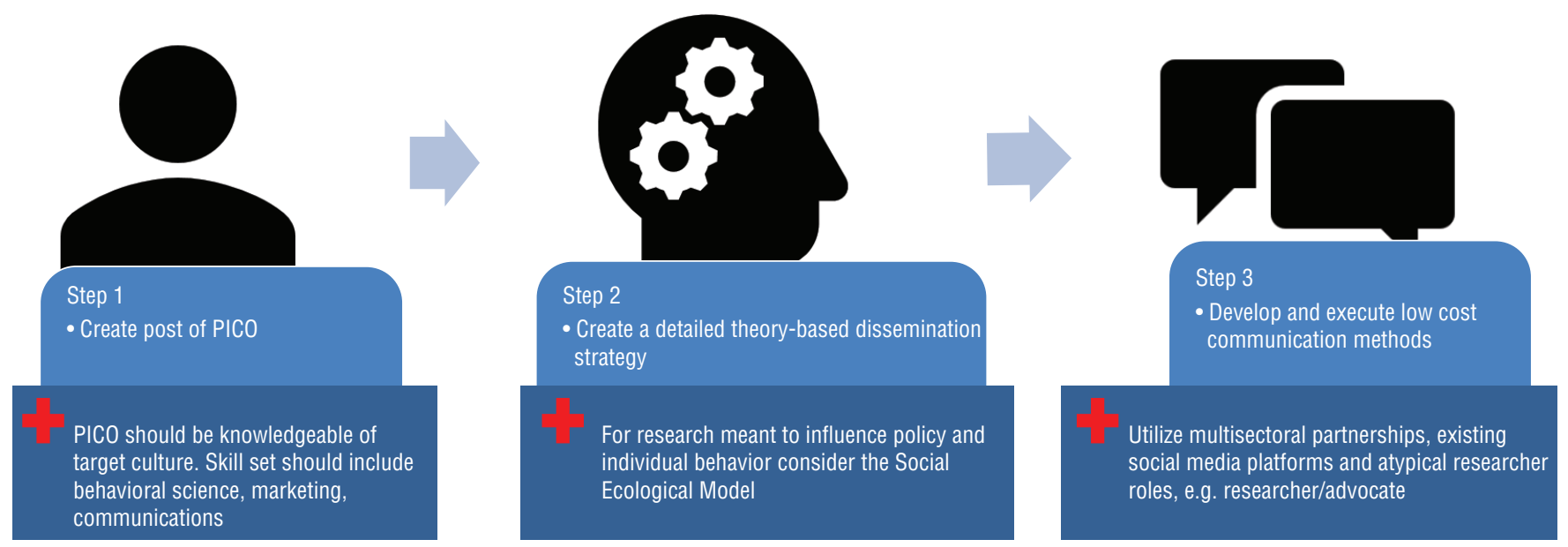

Source: Prepared by the authors from study data and based on the model by Golden SD, Earp JL. Social ecological approaches to individuals and their contexts: twenty years of health education \& behavior health promotion interventions. Health Ed Behavior. 2012;(39):364-72.

by policymakers (24-26). Of note, Rogers (6) stated that, "the innovation decision process involves moving from gaining knowledge to forming an attitude and this attitude is influenced by the vehicle of persuasion."

Combining the role of NCDs advocate and Principal Investigator during a research process and allowing that individual to continue to play a key role in the dissemination phase, helped to ensure that research findings were prioritized by those more likely to influence the adoption of recommended changes (27). In this work, the PI/NCDs advocate son RC, Guell C. The development of public policies to address non-communicable diseases in the Caribbean country of Barbados: the importance of problem framing and policy entrepreneurs. Int J Health Policy Manag. 2017;6(2):71-82.

2. World Health Organization, Pan American Health Organization. Core indicators: health situation in the Americas. 2016. Available from: http://iris.paho. org / xmlui / bitstream / handle / 123456789/31289/CoreIndicators2016eng.pdf? sequence $=1 \&$ is Allowed $=y$ Accessed 22 May 2018.

3. Samuels TA, Kirton J, Guebert J. Monitoring compliance with high-level commitments in health: the case of the CARICOM Summit on Chronic Non -Communicable Diseases. Bull World Health Organ. 2014;92(4):270-276B. doi: 10.2471/BLT.13.126128. should be considered as "knowledge broker" performing tasks related to effective knowledge transfer, networking, and capacity building.

It should be noted that in spite of the apparent success of the POSDEVAL model, there is inadequate research evidence to determine how to measure the effectiveness and impact of knowledge brokers on policy and practice (28). However, we maintain that the mixture of highly honed research and communication skills in the Principal Investigator of the POSDEVAL contributed greatly to the breadth and depth of dissemination activities.

\section{REFERENCES}

4. Samuels TA, Unwin N. The evaluation of the 2007 CARICOM heads of government Port of Spain NCDs summit declaration: the investigators' detailed report. 2017. Available from: http://onecaribbeanhealth.org/wp-content/uploads / 2018/01/POSDEVAL_The-Investigators-report_FINAL.pdf Accessed 28 February 2018.

5. Tetroe JM, Graham ID, Foy R, Robinson N, Eccles MP, Wensing M, et al. Health research funding agencies' support and promotion of knowledge translation: an international study. Milbank Q. 2008;86(1):125-55. doi: 10.1111/j.1468-0009.2007.00515.x.

6. Rogers EM. Diffusion of innovations. 5th ed. New York: Free Press; 2002.

7. World Health Organization. Module 5: Disseminating the research findings. WHO Document Production Services; 2014. Available from: http://www.who.int/ tdr/publications / year/2014/participant-
Funding. This work was carried out with the aid of a grant from the International Development Research Centre, Ottawa, Canada. The funders had no role in the study design, data collection or analysis, decision to publish, or preparation of the manuscript.

\section{Conflicts of interest: None declared.}

Disclaimer. Authors hold sole responsibility for the views expressed in the manuscript, which may not necessarily reflect the opinion or policy of the RPSP/ PAJPH and/or PAHO. workbook5_030414.pdf Accessed 22 May 2018.

8. Golden S, Earp J. Social ecological approaches to individuals and their contexts: twenty years of health education \& behavior health promotion interventions. Health Ed Behav. 2012; 39(3):364 -72. doi: 10.1177/ 1090198111418634

9. World Health Organization, Pan American Health Organization, CARICOM Secretariat. Accelerating action on NCDs: the evaluation of the 2007 CARICOM heads of government Port of Spain NCDs summit declaration. 2016. Available from: http:// onecaribbeanhealth.org/wp-content/ uploads / 2016/10/ACCELERATINGACTION-ON-NCDS-POSDEVALReport-1.pdf Accessed 22 May 2018.

10. Caribbean Unity in Health. Time to step up NCDs action, Health Ministers told at WHA. 2016. Available from: https://onecaribbeanhealth.org/time-to-step-up- 
NCD-action-health-ministers-told-atwha/ Accessed 22 May 2018.

11. Caribbean Unity in Health. Chief Medical Officers to make NCDs a priority. Available from: https://onecaribbeanhealth.org/ chief-medical-officers-to-make-NCDs-apriority/ Accessed 22 May 2018.

12. Caribbean Unity in Health. COHSOD: making progress in the NCDs response. Caribbean Unity in Health. Available from: http:/ / onecaribbeanhealth.org/cohsod-making-progress-in-the-NCDsresponse/ Accessed 22 May 2018.

13. Caribbean Unity in Health. NCDs central to COHSOD meeting. Available from: http:/ / onecaribbeanhealth.org/NCDscentral-to-cohsod-meeting/ Accessed 22 May 2018.

14. Caribbean Unity in Health. PAHO Director receives UWI-led landmark report on NCDs. Caribbean Unity in Health. 2016. Available from: http://onecaribbeanhealth.org/paho-director-receives-uwiled-landmark-report-on-NCDs / Accessed 22 May 2018.

15. The Caribbean Community and Common Market. Communiqué of the Thirty-Seventh Regular Meeting of the Conference of Heads of Government of the Caribbean Community (CARICOM), 4-6 July 2016, Georgetown Guyana. 2016. https://caricom.org/ media-center/communications / communiques/communique-issued-at-the-conclusion-of-the-thirty-seventh-regular-meetingof-the-conference-of-heads-of-government-of-the-caribbean-community-caricom-4-6-july-2016-georgetown-guyana Accessed 30 September 2018.
16. Caribbean Community and Common Market. Communiqué of the Thirty-Eighth Regular Meeting of the Conference of Heads of Government of the Caribbean Community (CARICOM) https:/ / caricom. org/cochog/view / communique-thirtyeighth-caricom-heads-of-government-meeting Accessed 20 September 2018

17. Caribbean Unity in Health. More facts, more figures, more implementation ideas. Available from: http://onecaribbeanhealth.org/more-facts-figures-and-implementation-ideas/ Accessed 22 May 2018.

18. Bernhardt JM, Mays D, Kreuter MW. Dissemination 2.0: closing the gap between knowledge and practice with new media and marketing. J Health Commun. 2011;16(Suppl 1):32-44. doi: 10.1080/ 10810730.2011.593608.

19. Liverani M, Hawkins B, Parkhurst JO. Political and institutional influences on the use of evidence in public health policy. A systematic review. PLoS One. 2013;8(10): e77404. doi:10.1371/journal.pone.0077404.

20. Almeida C, Báscolo E. Use of research results in policy decision-making, formulation, and implementation: a review of the literature. Cad Saude Publica. 2006; 22(Suppl):S7-33.

21. Milat AJ, Li B. Narrative review of frameworks for translating research evidence into policy and practice. Public Health Res Pract. 2017;27(1). doi: 10.17061/phrp2711704.

22. Kothari A, Wathen CN. Integrated knowledge translation: digging deeper, moving forward. J Epidemiol Commun Health. 2017;71(6):619-623. doi: 10.1136/jech-2016208490.
23. Andermann A, Pang T, Newton JN, Davis A, Panisset U. Evidence for Health II: Overcoming barriers to using evidence in policy and practice. Health Res Policy Syst. 2016;14(14):17. doi: 10.1186/s12961016-0086-3.

24. Mueller NB, Burke RC, Luke DA, Harris JK. Getting the word out: multiple methods for disseminating evaluation findings. J Public Health Manag Pract. 2008;14(2):170-6. doi: 10.1097/01.PHH.0000311896.65454.77.

25. Dobbins M, Jack S, Thomas H, Kothari A. Public health decision-makers' informational needs and preferences for receiving research evidence. Worldviews Evid Based Nurs. 2007;4(3):156-63.

26. Steiner JF. Using stories to disseminate research: the attributes of representative stories. J Gen Intern Med. 2007;22(11):1603-7.

27. Cavanaugh R. Alafia Samuels: fast-food watchdog in the Caribbean. Lancet Diabetes Endocrinol. 2017;5(10):772. doi: 10.1016/S2213-8587(16)30312-6.

28. Bornbaum CC, Kornas K, Peirson L, Rosella LC. Exploring the function and effectiveness of knowledge brokers as facilitators of knowledge translation in health-related settings: a systematic review and thematic analysis. Implement Sci. 2015;20;10:162. doi: 10.1186/s13012-015-0351-9.

Manuscript received on 23 May 2018. Accepted for publication on 22 August 2018.
RESUMEN

\section{Estrategia de comunicación para divulgar los resultados de la evaluación de la Declaración de Puerto España entre distintos públicos destinatarios en el Caribe}

Palabras clave
De modo similar al de otras naciones en la Región de las Américas, los países del Caribe se enfrentan a una morbilidad y mortalidad en aumento asociadas a las enfermedades no transmisibles (ENT). En el 2007, gracias al apoyo de sir George Alleyne, entre otros, la Comunidad del Caribe (CARICOM) celebró la primera cumbre de jefes de Gobierno sobre las ENT. Fruto de esta cumbre fue la Declaración de Puerto España, que supuso un punto de confluencia para acelerar la respuesta regional a las ENT, además de un catalizador para la primera reunión de alto nivel de la Asamblea General de las Naciones Unidas sobre las ENT, que tuvo lugar en septiembre del 2011.

En el 2014, siete años después de la cumbre de CARICOM sobre las ENT, se llevó a cabo una evaluación formal de la Declaración de Puerto España para investigar su repercusión y extraer las lecciones que respalden y aceleren en mayor medida su ejecución. Uno de los mecanismos consistió en evaluar los logros y retos en la respuesta a las ENT y comunicar eficazmente los resultados a los interesados directos y el público general.

En otros artículos de este suplemento se presentan los resultados de la evaluación y la ejecución de la Declaración de Puerto España. En el presente artículo se describe el proceso de comunicación e información social empleado para divulgar los resultados de la evaluación entre los distintos ámbitos de influencia social en el Caribe, especialmente entre los años 2016 y 2017. A modo de posible estrategia, se describen las principales medidas del plan de comunicación para divulgar la información relacionada con la investigación sobre las ENT y acelerar las medidas de control y la formulación de políticas en los pequeños estados insulares en desarrollo y los países de ingresos medianos.

Comunicación en salud; enfermedades no transmisibles; política de salud; Región del Caribe. 
RESUMO À semelhança de várias nações nas Américas, os países do Caribe enfrentam um aumento da morbidade e mortalidade associadas às doenças não transmissíveis (DNTs). Em 2007, fundamentada na defesa da causa feita por Sir George Alleyne e

\section{Estratégia de comunicação para disseminar os resultados da avaliação da Declaração de Porto de Espanha (POSDEVAL) entre públicos diversos no Caribe} outros, a Comunidade do Caribe (CARICOM) convocou a primeira Cúpula de Chefes de Governo sobre DNTs. Esta reunião culminou com a Declaração de Porto de Espanha que serviu não só como um ponto de encontro para acelerar a resposta regional às DNTs, mas também como um estímulo à primeira Reunião de Alto Nível das Nações Unidas sobre DNTs, em setembro de 2011.

Em 2014, sete anos após a Cúpula sobre DNTs da CARICOM, foi realizada uma avaliação formal da Declaração de Porto de Espanha (POSDEVAL) para avaliar o impacto produzido e os ensinamentos tirados a fim de subsidiar e acelerar sua execução. Uma das estratégias usadas foi examinar os êxitos e desafios na resposta às DNTs e comunicar de modo efetivo os resultados aos interessados diretos e ao público. Os resultados da avaliação e execução da Declaração de Porto de Espanha são apresentados em outros artigos neste suplemento. O presente artigo descreve o processo de comunicação e informação social usado para divulgar os resultados da POSDEVAL entre as diversas esferas de influência social no Caribe, sobretudo no período de 2016-2017. Os principais passos da estratégia de comunicação são partilhados como uma possível estratégia para disseminar dados de pesquisas sobre DNTs e acelerar o controle e a adoção de políticas em outros Pequenos Estados Insulares em Desenvolvimento e países de média renda.

Palavras-chave Comunicação em saúde; doenças não transmissíveis; política de saúde; Região do Caribe. 